Man and Nature

L'homme et la nature

\title{
Love, or Family Love, in New France. A New Reading of The Letters of Madame Bégon
}

\section{Catherine Rubinger}

Volume 11, 1992

URI : https://id.erudit.org/iderudit/1012682ar

DOI : https://doi.org/10.7202/1012682ar

Aller au sommaire du numéro

Éditeur(s)

Canadian Society for Eighteenth-Century Studies / Société canadienne d'étude du dix-huitième siècle

ISSN

0824-3298 (imprimé)

1927-8810 (numérique)

Découvrir la revue

Citer cet article

Rubinger, C. (1992). Love, or Family Love, in New France. A New Reading of The Letters of Madame Bégon. Man and Nature / L'homme et la nature, 11, 187-199. https://doi.org/10.7202/1012682ar

Copyright (c) Canadian Society for Eighteenth-Century Studies / Sociéte canadienne d'étude du dix-huitième siècle, 1992
Ce document est protégé par la loi sur le droit d'auteur. L'utilisation des services d'Érudit (y compris la reproduction) est assujettie à sa politique d'utilisation que vous pouvez consulter en ligne.

https://apropos.erudit.org/fr/usagers/politique-dutilisation/ 


\section{Love, or Family Love, in New France. A New Reading of The Letters of Madame Bégon}

From the time of their discovery, the letters of Mme Bégon to her son-in-law ${ }^{1}$ have not merely interested historians as a rich source of details about daily life in the governing classes of New France, but have also fascinated their readers by the human interest aspect. All her biographers and editors have interpreted them as a love story. 'Sur la nature de ses sentiments à l'égard de Villebois, je crois qu'il ne peut guère subsister de doute,' wrote Claude Bonnault. 'Rien que le fait du tutoiement est révélateur, surtout à cette époque. Qu'elle l'ait de temps en temps, appelé son "cher fils" n'infirme en rien ces conclusions. L'amour chez les femmes, ne se plaît-il pas souvent à prendre des couleurs maternelles? et puis, n'oublions pas que nous sommes au moment de J-J. Rousseau et de Mme de Warens.... Il y a des contagions morales, des modes de sentiments, comme il y a des modes de costumes. ${ }^{2}$ Nicole Deschamps says: 'Cette belle-mère amoureuse adressait des lettres à son "cher fils" pour ne pas mourir d'être séparée de lui.. ${ }^{3}$

The main arguments for their view are that Mme Bégon expresses her emotions in passionate terms, that she refers to the separation from her son-in-law as very painful, that she addresses him in the familiar 'tutoiement,' and that de Villebois was so unattractive that only infatuation could explain her love.

This view of the sensible, likeable Mme Bégon as the victim of blind passion has caused all her biographers perplexity, but none have challenged it. Yet it is possible, through an analysis of the text as if it were a novel, with attention to style and the characters involved, to suggest an alternative interpretation.

It is true that in the early stages of his absence, Mme Bégon writes to her son-in-law every day, and that her expressions of affection and regret for his absence are frequent, emotional and florid: 'Les jours me paraissent des années, éloignée de toi ...' (230) and '... ton absence, cher fils, m'est insupportable ...' (295), but much of this hyperbole can be discounted as the style of the period, where expressions of regret for absence and assurances of friendship, even of love, are a necessary 
courtesy, a convention practised by, and of, both sexes. D'Alembert writes to Voltaire, for example: 'Mon compagnon de voyage' (Condorcet) 'qui regarde le temps où il a été chez vous comme un des plus heureux de sa vie, vous embrasse et vous aime de tout son coeur ${ }^{\prime 4}$ and Julie de Lespinasse writes to Condorcet: 'Adieu monsieur, mon secrétaire, (d'Alembert, her companion/lover) ... ne m'empêchera pas de vous aimer de tout mon coeur ...' and 'Adieu, mon bon Condorcet, mon secrétaire et tous vos amis vous embrassent, vous aiment et vous regrettent.... ${ }^{5}$

Mme Bégon also attributes the same emotions in the same hyperbole to and about other members of the family: 'Mon cher père te fait mille tendres amitiés. Il te demande comme moi de nous aimer autant que nous vous aimons ...' (306). Her son, Bégon, she tells de Villebois, 'meurt d'envie de te voir' (284). His daughter joins her in weeping over his letters: 'Notre chère petite ne cesse de baiser ta lettre et nous avons pleuré de joie ensemble en la lisant' (181). She misses other young members of the family, too: '... je ne m'accoutumerai jamais à être séparée de toi, ni de mon cher petit Villebois ...' (200).

Love in the plural is indeed her characteristic mode of expression, as if by writing she can reconstitute in her mind the fractured family, and also remind the absent one of the chain of love, linking him to home. 'Mon cher père ne souhaite vivre que pour te revoir. Il attend le temps avec bien de l'impatience et ta fille et moi, sans oublier le petit frère et beau-frère qui te sont tous aussi attachés les uns que les autres' (183). In brief, Nicole Deschamps' picture of a 'belle-mère amoureuse' writing to her son-in-law 'pour ne pas mourir d'être séparée de lui' ${ }^{\prime}$ is constantly belied by Mme Bégon's own insistence that she is speaking for the family to a beloved absent member of a close-knit group. 'En vérité, cher fils, c'est un grand malheur de s'aimer aussi parfaitement' (183).

Mme Bégon's biographers have, moreover, often tended to assume that the correspondence and the grief it expresses were one-sided, even neurotic. One, for example, refers to her as a woman 'qui aimait son gendre de passion, sinon d'amour' and comments: 'Est-ce encore aimer que de consacrer sa vie à écrire à celui qui ne vous aime pas? Occupation stérile et cruelle où même le masochisme féminin le plus exacerbé finirait par s'épuiser. ${ }^{7}$ Yet there is evidence that Mme Bégon's letters were an attempt at a dialogue, severely hindered by the erratic nature of the mail. She refers to his opinions (185), she laughs because he has complained she didn't write often enough, and quotes his words: 'Tu me dis, en dernier lieu, qu'il faut nous dire tout ce que nous pensons par écrit puisque nous ne pouvons nous voir' (222). At other times, she is obviously replying to his expressed anguish for his loneliness. Once again, it is a family message that she sends in reply: 'Ne pense pas, cher fils, 
que notre séparation te soit plus dure qu'à nous et surtout à moi. Il est des moments où elle m'est insupportable' - then going on to exclaim over the delay in receiving mail - 'Tous ces retardements ne font qu'augmenter la peine que j'ai de te voir si éloigné par inquiétudes réciproques que nous avons. De telles séparations ne sont point faites pour des familles aussi attachées que nous le sommes' (187).

As for the fact that she 'tutoies' him, this is not a conclusive argument either way. On the one hand, the 'tutoiement' is not, as Claude Bonnault implies, a clear proof of passion. In the letters and novels of the period, lovers in fact most frequently address each other as 'vous.' Only in moments of exceptional emotion, or where novelists are evoking exotic or particularly innocent characters, do lovers say 'tu' to each other. On the other hand, nor is 'vous' necessarily the universal norm for speech among family members and friends, even in France at the period. The prevalence of 'vous' in published works may be dictated by literary considerations rather than realism in a milieu where style was of immense importance. This is suggested by the fact that in moments of intense feeling, both in fiction and in letters, 'tu' is used by people (not only lovers) who normally say 'vous' to each other. In Le paysan parvenu, for example, during an emotional reunion, brothers alternate between 'vous' and 'tu,' as do father and sons, and that this use of 'tu' is not a class phenomenon, but an expression of closeness, is shown when at one point, the hero is addressed, in a moment of passionate gratitude, by his friend, a Count, in the 'tu' form. ${ }^{8}$ Condorcet on his death-bed wrote to his daughter addressing her as 'tu.'

It is possible, too, that in New France the use of 'tu' was then, as now, more frequent than in France. A contemporary of Mme Bégon, the Veuve Benoît, wrote to her brother, François Baby, using 'tu. ${ }^{10}$ Eighty years later, we find Julie Bruneau writing to her husband Louis-Joseph Papineau in the 'tu' form, and as the editors of L'histoire de la Femme au Québec remark, 'La femme de Papineau est un personnage public dans la petite société du Bas-Canada. Son moindre geste peut avoir une signification politique et elle est obligée d'en tenir compte. ${ }^{11}$ Examples of mothers writing to sons (or sons-in-law) are, unfortunately, rare. Marie de l'Incarnation wrote to hers, using 'vous,' but her letters were intended to be edifying, written knowing that they would be read by others; and she was, moreover, French by birth and education.

Unfortunately, too, there are insufficient examples of reported dialogue in Mme Bégon's letters for one to form a clear picture of normal usage in her family. Children then, as now, evidently said 'tu' to adults while they were small, and learned to say 'vous' as their social horizons expanded. Mme Bégon's grand-daughter addresses all the adults of the household as 'tu' (pp. 61, 85, 99). Mme Bégon, who says 'vous' to her 
father, also says 'vous' to the child, but at that time she was teaching the little girl and this could be part of a plan of social training. La Gallissonière, a family friend very devoted to the child, addresses her as 'vous' (83). The child says 'vous' to him (80) and to the priest (58). She alternates between 'tu' and 'vous' when she writes to her own father. Since she wrote unsupervised we can assume that she wrote as she spoke. The spontaneous messages contain ' $t u$,' whereas the polite formula at the end learned by heart uses 'vous' $(196,199,201)$. As time goes on and the child grows older, as she writes better, and her memory of her father grows dimmer, the 'tu' becomes less frequent $(251,254)$ and then disappears $(259,265,269,307,310)$. It would seem, therefore, that girls learned to write 'vous' to their men-folk, their elders at least. However, Mme Bégon is addressed as 'tu' by the only other adult of her age in the household, her friend and companion, Mater (162). When addressing de Villebois, she alternates between 'tu' and 'vous,' using 'vous' as one would expect when she is angry and hurt (190, 284-5, 314); and it is clear from the context that, whereas the 'tu' expresses confidence and trust, the 'vous' form is a mark of rejection, exclusion. De Villebois is no longer one of hers: she does not recognise him, she says. She reverts to 'tu' when the family ties reassert themselves in her mind, and affection surmounts anger.

One might conclude that then, as now, the 'tu/vous' usage depended much on the social situation. 'Vous' was the accepted norm, (but for mothers and sons?) 'tu' a mark of family intimacy and affection. In Mme Bégon's household it is clear that there was little distinction made between relations by blood and relations by marriage. Not merely does she call de Villebois her son, but her biological son calls de Villebois his brother. Her grand-daughter calls her 'maman,' a name she also gives to one of her aunts. If there were households where mothers said 'tu' to their sons, then in this close-knit family Mme Bégon's use of 'tu' to her son-in-law would not be surprising.

Whatever the usage, it is very difficult to believe that she would have written a form that was outside the accepted conventions. She was a woman who prided herself on her discretion. She lived in a world where letters performed the function of modern newspapers, their contents, widely circulated among mutual acquaintances. She reminds de Villebois to destroy her letters meant only for him, but was quite right in thinking that he would probably not do so. It is difficult to believe that she would have used a style of expression so compromising that it could have ruined his reputation and hers.

Mme Bégon's biographers have found other aspects of the passionate infatuation interpretation even more difficult to believe. 'On accepte comme aïeule une improbable statue de la résignation, de la sagesse et 
du devoir, mais comment imaginer qu'elle eût pu être amoureuse de son gendre jusqu'à la folie ? $^{\prime 2}$ It would be difficult to imagine if it were so, but de Villebois was not the principal object of Mme Bégon's affections, and his absence was not the main cause of her grief. She had recently lost her husband, a man whom she had married 'à la gaumine' in defiance of their families and the archbishop's edict. Their love affair had been one of the 'causes célèbres' of the day, their marriage probably the main reason why, despite his birth and connections, his promotion was slow. Governor of Trois Rivières, he had had hopes of the governorship of Montreal when he died suddenly, relatively young. She speaks of her bereavement in restrained tones, quite unlike the ebullience of her usual style of expression. This contrast makes it clear that de Villebois' absence was only a secondary source of pain. 'Je ne puis soupirer, tantôt de ton absence, tantôt de ce que le Seigneur m'a ôté, dont je ne puis me consoler. Plus je vais et plus je sens la perte que j'ai faite' (40), she writes, and 'Si je $t^{\prime}$ avais, cher fils, auprès de moi, ou que je fusse avec toi, je $m$ 'imagine que je n'aurais plus de chagrin ou, du moins, je le prendrais plus doucement' (172). Once again, it is as a member of the family group that she addresses him on the anniversary of her husband's death: 'Il y a aujourd'hui un an, cher fils, que j'ai perdu $M$. Bégon.... J'espère que partout où tu seras, tu n'oublieras point à joindre tes prières aux nôtres ...' (120). And the next day, referring to the visit of a family friend who had called to express condolences, she includes de Villebois in a long rambling plaint which begins with tears for her bereavement and ends in anxiety for her little son and grandson: 'La vue d'une personne qui était aussi chère à ce que nous pleurons tous a achevé de $m$ 'abattre. Il ne diminue rien de ses bontés et attentions pour nous. Il aime cette chère petite beaucoup et voudrait comme moi, qu'elle fût parfaite.... Elle est aussi, je te l'avoue, toute ma consolation. Elle se porte assez bien et prie le Seigneur de tout mon coeur de me la conserver ainsi que mon cher fils, son père, dont je voudrais bien savoir des nouvelles et de mon petit Bégon et Villebois. J'avoue que ce dernier me tient bien au coeur. Ce cher innocent est seul de son espèce, dans un endroit où il est peut-être grondé bien fort ...' (121).

Nicole Deschamps, reacting, in her 'Présentation' of the published letters, to such multiple griefs, finds Mme Bégon an interesting prototype of French Canadian fictional heroines: 'Quelle figure de "mère québécoise" que cette femme éprise et martyre, souriante et souffrante....! Elisabeth Bégon pourrait être l'aïeule d'une héroïne qui réunirait les caractéristiques de Donalda, d'Angelina Desmarais et de Grand-Mère Antoinette, et celui à qui elle écrivait, son gendre et 'cher fils'... compose, par plusieurs de ses traits, un personnage de 'survenant' manqué. ${ }^{13}$ 'Notre littérature,' she comments, 'est remplie de ces héros 
amers et décevants ... et d'héroïnes aggressivement sacrifiées, impuissantes à rendre leur beauté accessible et qui à défaut d'être aimées, se résignent à jouer l'horrible personnage de mère auquel les contraint le regard infirme de l'homme..14

There is some resemblance, certainly to the characters of the early novel, and perhaps even more so to the sad, valiant mothers of Gabrielle Roy's work, notably in the themes of lost happiness, absence, and struggle against adversity. But where the novels tend to focus on the frustrated lives of a young couple, Mme Bégon's tragedy is that of old age. And where the novel is usually, at some level, about the loss or absence of freedom, the inability to love and achieve self-fulfilment, personal and collective, Mme Bégon's story is that of a woman who has known all these. Though like her fictional descendants who also experienced sorrow, hardship, and heart-break, she is a very different sort of person from them, living in a very different society. The heroine of the 'roman de la terre' lives in a circumscribed world; she is essentially powerless and her potential for happiness is frustrated before it fully blooms. Confined to the home, the farm, the land on which she is raised, she has little knowledge of the world around her, few resources, and so no real opportunity to influence her destiny. Her only experience of adventure, freedom, and love, comes through a man, and vanishes with him. When he leaves or dies, all that remains for her is, at best, to learn a patient acceptance of her traditional role, living out a life of toil, lit only by a fatalistic faith and an inherited ideal of loyalty to the land and her 'race.' The ideal is presented as beautiful, the sacrifice as noble, even of mystic importance, to a Quebec in an insecure historical moment, inward-looking, nostalgic for the past, unsure of the future. Later generations of readers and of novelists, however, at another historical moment, would see in these novels the sombre, masochistic, potentially destructive aspect of a sacrifice accomplished in an atmosphere of frustrated hope, repressed sensuality, and resignation to the loss of freedom, love, spontaneity, and joy.

Nothing could be more unlike Mme Bégon's world. She is indeed less a prototype of French Canadian fiction than an authentic embodiment of that lost happy past for which the characters in the novels are so often nostalgic and from which, in their darkest hours, Québécois have derived their courage and national pride. Her world, though often problem-ridden, and darkened by a chronic shortage of money, by the threat of war, and insecurity born of Versailles' neglect and inner corruption, is still a dynamic, forward-looking society. Her youth had coincided with the heyday of New France and in her maturity, she had presided over the witty, extravagant, and colourful dinner tables of the colony's privileged class. Short of money now and getting old, she still 
has the gaiety and energy of that dynamic period. Her household is prone to headaches, perhaps from tension or stress, and to all the ills of winter flu and coughs and chilblains, but there is no evidence of frustration, and Mme Bégon herself has nothing of the repressed neurotic. She has had a rich colourful, love-filled life. Unlike the fictional heroines, she is a person of many moods, and the sorrowful resignation of the 'mater dolorosa' is neither her normal attitude nor one that lasts long when she succumbs to it. It is true that she quite often signs her letters with the formula 'plains ta mère,' but this is common in eighteenth-century correspondence and has none of the manipulative demand for generalised pity characteristic of masochism. She is quite frank about her need for sympathy, and makes it clear what form she wants it to take: 'plains-moi' means 'write to me.' Mme Bégon is always in touch with her emotions. She expresses them openly and by doing so often lightens her own mood, releasing her humour and wit.

Mme Bégon was, moreover, far from helpless, nor had she lived a confined life. Her horizons and her correspondence stretch to the confines of two continents. Unlike the fictional heroines mentioned, she understood the institutions in which she lived and could communicate, as an equal, with the men who controlled them. Though she longed for a shoulder to lean on, and asked advice readily of De la Gallissonière and de Villebois' brother, she did not rely on them to solve her problems. When her widow's pension does not come, she petitions for it, struggling with the nepotistic jungle of colonial bureaucracy; when, in France, she discovers that the Bégon revenue comes from wine, she studies viticulture, visits the vineyards, discovers bad management and makes changes, all long before de Villebois has sent his advice. When de Villebois disgraces himself and the family, it is she who petitions in high places, to put matters right. Only in the matter of a reunion with de Villebois does she permit herself an illusion, and even there, she does not passively sit at home waiting for his return, but moves the whole family to France in the vain hope of being near him and her own young son.

There is indeed a vast social and historical gulf between Mme Bégon selling her own house, making her own decisions and poor bewildered Rose-Anna Lacasse plodding wearily round St. Henri in search of an ever cheaper lodging to rent. Mme Bégon may be short of money, but she has property, she hopes for a pension, and at the worst she has influence and the habit of authority. She is, in fact, a member of the governing classes, not merely as the widow of a governor, but as a person in her own right. This too sets her worlds apart from the fictional heroines. When the Survenant leaves, when Rose-Anna's husband and son go to war, they vanish, for reasons only dimly understood by those 
they leave behind, into some mysterious outside world. But Mme Bégon not merely knows why De Villebois is absent, she is indeed partly responsible for it. She reminds him of the reasons: 'Travaille donc à revenir dans cette chère famille, mais travaille solidement et à y faire ce que l'on veut que tu y fasses: car on ne t'y a pas envoyé pour manger le tien, mais bien pour y arranger tes affaires' (280). That she is part of the 'on' who sent him away is clear from several other references to her influence $(266,282-83)$. She longs for his return but not at any price. 'Il n'y a que ton retour, cher fils, qui puisse me consoler, mais je ne le souhaite qu'autant qu'il sera ton avantage et que la chose sera convenable. Je ne t'aime pas pour moi seule et je veux que tu y aies toujours la meilleure part' (296). She finds his absence hard to bear but it is part of her value system: she understands and approves its necessity.

She writes indeed with the informed mind, the wit and the self-confidence of a person with a clear vision of her purpose in life and the importance of her role to the fabric of society. She is aware and proud of herself as a personnage in her own right: 'L'estime que ta mère s'est acquise dans le pays lui donne la confiance et l'amitié de personnes qui peuvent beaucoup,' she tells de Villebois (262). Though bitterly offended by the scorn of her French family who refer to her as the 'Iroquoise,' she shows no other signs of being impeded or frustrated by the 'malaise propre à qui cherche une identité culturelle conciliant la fibre "iroquoise" et la fibre "française" dans un pays naissant ...' (20). She is, on the contrary, fully conscious of being part of a civilisation whose values and customs she knows in all their strength and weaknesses.

Nor is being a mother for her a sterile or masochistic task. Holding the family together in New France was a significant and important role, the key to collective survival, for the colony was a network of interrelated, interdependent families. It was the task of the women to go out into the world, as diplomats for their family, like the salon hostesses of Paris, entertaining and corresponding with the most notable men of their day. There is clearly such a partnership between Mme Bégon and de Villebois. She has the influence, he gets the posting. Moreover, as head of the family, she does not hesitate to send him instructions, between two expressions of motherly affection. Energetic and confident of her priorities, she has moments of impatience with his over-scrupulous honesty and exhorts him to do as other men do in order to make money fast. A mutual acquaintance, she tells him,

a de l'argent et s'il en veut donner, il réussira; c'est par là que tout s'arrange en ce monde, à ce qu'il m'a dit. Et il me disait hier que tu aurais grand tort de ne pas faire tes affaires où tu es, puisque personne ne se fait de mystère de faire des 
commerces ouverts de toute espèce; et on regarde au bureau bien fous ceux qui font autrement et qui font manger leurs biens.... Ainsi, profite donc, cher fils, de leurs leçons et travaille en conséquence afin de revenir bientôt rejoindre une mère qui ne peut s'accoutumer à être séparée de toi, un papa qui meurt d'envie d'être réuni avec toi, une fille qui ne respire qu'après "sa chère mine" et qui soupire après ce cher père. (250)

At another moment, she calls him to order with some asperity, checking a certain crusading tendency at odds with the practicalities expected of him: 'Songe, cher fils, qu' on t'a mis où tu es que pour arranger tes affaires et point pour y être le réformateur du gouverneur' (266). Her harshest scolding comes from his letting the family down. He has embarassed all his relatives, including the young ones with careers to make. '[Je] suis d'une mortification que je ne puis te dire lorsque je les vois et que je pense à ce que tu as fait' (266), but she still tries, like a loving mother, to find excuses for him, to forestall and disarm his predictably angry rejection of her advice, to save his face by motherly explanations of her severity:

Je ne te reconnais point, je ne t'ai point vu ces petitesses. Y aurait-il quelqu'un à te pervertir, de façon à te faire un tort considérable? ... N'écris jamais dans ton premier mouvement.... Adieu. En voilà peut-être plus que tu n'en voudrais, mais tu me touches de trop près pour te cacher des choses aussi essentielles, et tu dois m'en aimer davantage, puisque si tu m'étais moins cher, je ne te dirais rien.... Adieu, cher fils. Aime ta mère qui t'aime plus que tu ne l'aimeras jamais. $(261-62)$

The tone of these last letters, alternately horrified, exasperated, affectionate, determindedly reasonable, resemble those of Mme d'Epinay, ${ }^{15}$ Mme Houdetot, ${ }^{16}$ and others to Rousseau in the same circumstances. This and his stormy behaviour and subsequent mental illness have given some colour to the theory that Mme Bégon was, as Claude Bonnault suggests, unconsciously playing Mme de Warens to de Villebois' Rousseau. It is not known whether le 'cher fils,' like Rousseau, called Mme Bégon his 'très chère Maman' ${ }^{17}$ but their relationship certainly followed the same pattern of affection eroded by neurosis as that of Rousseau with a succession of women. However, this is not in itself a proof of the 'contagion morale' suggested by Claude Bonnault. Nowhere indeed in her letters does she express the intense preoccupation with her own sentiments, nor the self abnegation of such authenticated passions as that of Mme du Deffand for Walpole, or Julie de Lespinasse for Guibert. Julie, attempting to justify her suffering in a 'roman de l'amour 
impossible, ${ }^{18}$ writes: 'Oui, mon ami, je vis tout en vous, $j$ 'existe parce que je vous aime, et cela est si vrai qu'il me paraît impossible de ne pas mourir quand j'aurai perdu l'espoir de vous voir. ${ }^{, 19}$ Mme du Deffand pleads and cajoles Walpole, reduced to childishness, despite her better judgement. 'Que de làcheté, de faiblesse et de ridicule je vous ai laissé voir! je m'étais bien promis le contraire; mais, mais.... Oubliez tout cela, pardonnez-le-moi, mon tuteur, et ne pensez plus à votre petite que pour vous dire qu'elle est raisonnable, obéissante, et par-dessus tout reconnaissante.... ${ }^{20}$ Mme Bégon never loses her dignity in this way. Nor does she, unlike Rousseau's admirers, ever wholly abandon him. When wounded to the heart by de Villebois, she lets six months go by without writing at all and then, when she resumes, she adresses the stranger he has become with the 'vous' form of cold dignity, but she makes it clear that she has not lost all hope that things can be put right. One of her biographers has seen in these last letters 'la froideur des partages légaux entre gens bien élevés qui divorcent. ${ }^{21}$ Yet Mme Bégon continues to try and reach her dear son through the clouds of his mania and her grief. The 'tutoiement' breaks through and her final message is affectionate: 'Adieu, mon très cher fils. Je vous demanderai toujours avec instance de ménager votre santé qui m'est infiniment chère, malgré le chagrin que vous m'avez donné.... Adieu, je t'embrasse mille et mille fois et serai, toute ma vie, ta tendre et trop bonne mère.' This takes considerable will power - but 'je ne suis pas mère pour rien,' she remarks grimly — for she does not like, still less love, the man her son-in-law has become.

That is, however, the de Villebois on which the biographers dwell. Isabel Landels muses with perplexity about 'ce gendre qui finit par lui briser le coeur, ${ }^{\prime 22}$ Céline Dupré writes: '... l'objet d'une affection aussi ardente et indéfectible ... était d'un naturel peu agréable, si l'on en juge par le caractère orageux de sa carrière et les dernières lettres de Mme Bégon.... ${ }^{23}$ Nicole Deschamps echoes the same themes: 'Etrange homme que ce Michel de Villebois de la Rouvillière. Physiquement il est laid, obèse et de santé fragile. Moralement, il a un caractère ombrageux.... ${ }^{24}$

As a lover, this 'absent qui avait mauvais caractère, et dont le charme demeure mystérieux ${ }^{25}$ is indeed unattractive. But the man to whom Mme Bégon confidently addresses her letters is a quite different person: an attentive and sympathetic member of a household where life was an intense mixture of grief and fun, where everyone is teased, given a nick-name in the style of the period. She is de Villebois' 'vieille grandmère' (308) and his 'mère grognonne'; her real son calls his brother-inlaw 'son bandit' (306), and she and his sister scandalise the little girl by their irreverent names for 'le cher fils,' his sister calling him 'gros cochon,' Mme Bégon retorting with 'ange bouffi' (276). Elsewhere she calls him 'mon gros cochon de fils,' which recalls Mme d'Epinay's pet 
names for Rousseau of 'mon hermite' and 'mon ours. ${ }^{26}$ She refers often, in a semi-teasing, semi-serious way, to his corpulence, and advises him to eat less and take exercise for his health, and she also refers to his interest in another woman (219) and advises him to 'évite(r) les belles' (281). Teasing de Villebois is obviously a family entertainment. Difficult, moody, insecure, and overweight he may have been, but in the warmth of home he was obviously also lovable, gifted, witty, a bit over-sensitive perhaps, but fundamentally admirable. An impractical, insecure idealist whose judgements of people would go dangerously awry, who easily fell victim to feelings of persecution when unsupported by people who valued him, he was a man who needed family affection. Mme Bégon was accustomed to providing it. Both enjoyed a sympathetic ear and a foil for their wit. This surely is the simple explanation of the attraction between them?

They had, moreover, a great deal in common. They were much the same age. They shared a common sorrow in the death of his wife, her daughter. He had supported her when her husband died. She had lost all but one of her four children. He filled some of the gap left by those losses, the grown-up son she never had. He was a relative and therefore shared her family concerns, and also a friend in the eighteenth-century manner - as keenly interested in her physical ailments as in the latest society gossip. He consoled her when her head ached, encouraged her to take her medecine when she was sick, condoled with her harrowing constipation, gave advice about her son, her brother, and an assortment of nephews and relatives who caused her concern, and helped to entertain her father. They shared a common interest in politics and people, keenly passing on the news of who was being promoted, who married, who appointed to the top positions in their world. They had a common scorn for the 'grosses têtes.' Together, they could indulge in little 'parties de médisance' (69).

In her portrait, he is neither ugly nor unkind. She refers to his fine eyes, and often calls him 'aimable' and refers to his kind heart - usually, as mothers do, when she thinks he is in danger of forgetting it, or when she wants him to give a helping hand to some protégé of hers. She assumes that he will consider this, as she does, part of the family duty $(183,242)$. All this, and loneliness, explain why her most frequent explanation of what she misses by his absence is someone to confide in, a 'consolation' $(225,191,249)$. She often refers to the lack of another intimate friend. 'Qu'il y a des moments, cher fils, où je souffre et que de larmes je verse sans rien dire! Et à qui le dirai-je, hors que ce ne fût à ma chère petite? Mais il est inutile de lui donner du chagrin à son âge...' (186). 
Yet he is not her only consolation. In implying that he is indispensable, she flatters him a little, for her world is less empty than she implies. Other 'consolations' are her grandchildren (259), the absent Mater (157, 224-25) and Monsieur de la Galissonnière, her nephew by marriage and acting govenor of New France (202). Her relationship with the latter is obviously similar to the one with de Villebois, if rather more respectful. M. de la Galissonière calls daily when he is in town, staying a while to talk politics, giving her financial advice, offering practical help, lending a sympathetic ear to the anxieties caused by her son or younger brother, bringing her news, encouraging her when she is sick, and taking a sustained interest in the little girl's education. Her granddaughter is indeed the greatest consolation for Mme Bégon, and also the most abiding tie with de Villebois. Taking the place of the child's dead mother, she reports to him the smallest details about the child's looks, size, and character. Her amusement and rueful pride in her spirited granddaughter are certainly one of the reasons why her son-in-law is always so near to her heart, his well-being so important to her, his absence so constantly noticed.

All Mme Bégon's biographers are intensely partisan, seeking to compensate for de Villebois' weakness by giving her story an emotional grandeur worthy of her. To see her as a woman involved in a grotesque passion for her son-in-law, is to misrepresent and underrate the complexity of her personality and the degree to which she defined herself as a reasonable woman, a woman of social influence, and as a mother, head of a family. Blows to the ego and to the social reputation suffered by women with a passing maternal passion for a Rousseau or a d'Alembert could be lived down. Mme Bégon's afflictions could not be lived down. They came too late, at the end of her life. And they went too deep, striking to the heart of her value system, her raison d'être, depriving her of all she held dear. Not merely did she suffer from de Villebois' misfortunes, from his resultant ingratitude and injustice, his madness would result in her losing her grand-daughter, too, her last, and perhaps most dearly loved, child. His death would make her exile pointless, her poverty, loss of social prestige, and loneliness permanent.

In sickness and in health, therefore, Mme Bégon's son-in-law played a critical role in the drama of her life, not as a passing object of infatuation, but as an integral part of her family, source of great pleasure and great pain. He was, for her, the 'cher fils' she called him.

\section{CATHERINE RUBINGER}

Mount Saint Vincent University 


\section{Notes}

1 Lettres au cher fils. Correspondance d'Elisabeth Bégon avec son gendre (1748-1753):

Préface de Nicole Deschamps, Hurtubise HMH, Montreal, 1972.

(Quotations from Mme Bégon's letters are referenced by page number in the text of the article.)

2 Lettre de Claude Bonnault, 4 février 1947, citée par Isabel Landels, dans: 'La correspondance de Mme Bégon,' thèse présentée à la Faculté des Lettres de l'Université Laval, 1947.

3 Présentation de Lettres au cher fils: Nicole Deschamps, op. cit., 26.

4 D'Alembert à Voltaire, le 4 déc. 1770. Quoted by Elisabeth et Robert Badinter in Condorcet. Un intellectuel en politique. Fayard, 1988, 68.

5 Julie de Lespinasse: Lettres à Condorcet, Desjonquières, Paris, 1990.

6 Nicole Deschamps, op. cit., 26.

7 Ibid., 26.

8 Marivaux: Le paysan parvenu, Gallimard, Paris, 1986, 390, 391, 414, 472, 482.

9 Quoted by E. and R. Badinter, op. cit., 60.

10 Mme Baby, Veuve Benoît, Archives de l'Université de Montréal, boite 115.

11 Julie Bruneau à Louis-Joseph Papineau, le 15 déc. 1831, Rapport de l'archiviste de la province de Québec, 1957-1958, 65. Quoted by Nicole Brossard and Andrée Yanacopoulo in L'Histoire des Femmes au Québec, Quinze, Montréal, 1982.

12 Nicole Deschamps, op. cit., 15.

13 Ibid., 13.

14 Ibid., 27.

15 Mme d'Epinay à Rousseau: Correspondance générale, Librarie Armand Colin, Paris, 1926, III, 39.

16 Mme de Houdetot à Rousseau in Ibid., III, 178.

17 Rousseau à Mme de Warens in Ibid., I, 135; and Mme de Warens à Rousseau, 325.

18 Jean-Noël Pascal: 'Notice,' introducing: Lettres de Mlle de Lespinasse, Editions d'Aujourd'hui, 1978.

19 Julie de l'Espinasse, op. cit., Lettre XXV11.

20 Madame du Deffand et son monde: Benedetta Craveri, Seuil, Paris, 1987, pp. 267, 303.

21 Nicole Deschamps, op. cit., 24.

22 Isabel Landels: 'La Correspondance de Mme Bégon,' 33. (See Reference 2.)

23 Céline Dupré: Elisabeth Bégon: Textes choisis, présentés et annotés, Fidès, Montreal, 1960. Introduction, 9.

24 Nicole Deschamps, op. cit., 18-19.

25 Ibid., 26.

26 Mme d'Epinay à Rousseau in Rousseau: op. cit., II, 299, 345. 